Available online at GSC Online Press Directory

GSC Biological and Pharmaceutical Sciences

e-ISSN: 2581-3250, CODEN (USA): GBPSC2

Journal homepage: https://www.gsconlinepress.com/journals/gscbps

(RESEARCH ARTICLE)

\title{
Molecular characterization of the pathogen responsible for Choanephora fruit rot disease in Momordica charantia (L.) and establishment of its ecofriendly control measures
}

Chowdhury Md. Estiak Khan 1,2, Chaity Arnaba Saha 1,3, Khan Alam ${ }^{4}$, Ferdouse Khandker Jannatul 1,5, Islam Md. Asadul ${ }^{1}$, Sikdar Biswanath ${ }^{1}$ and Hasan Md. Faruk ${ }^{1, *}$

${ }_{1}^{1}$ Department of Genetic Engineering and Biotechnology, Faculty of Biological Sciences, University of Rajshahi, Rajshahi6205, Bangladesh.

${ }^{2}$ Institute of Microbiology, Friedrich Schiller University Jena, Fuerstengraben 1, 07743 Jena, Germany.

${ }^{3}$ Institute of Biological Sciences, University of Rajshahi, Rajshahi-6205, Bangladesh.

${ }^{4}$ Department of Pharmacy, Faculty of Sciences, University of Rajshahi, Rajshahi-6205, Bangladesh.

${ }^{5}$ Department of Agricultural Extension, Kharmarbari, Farmgate, Dhaka-1215, Bangladesh.

Publication history: Received on 02 June 2020; revised on 06 June 2020; accepted on 10 June 2020

Article DOI: https://doi.org/10.30574/gscbps.2020.11.3.0161

\begin{abstract}
The present investigation was carried out to characterize the pathogen responsible for Choanephora fruit rot disease in bitter gourd along with find out appropriate control measure using biological resources. The pathogenic fungal strain was isolated from the disease infected fruit part of bitter gourd. It was subjected to four different types of growth media named potato dextrose agar (PDA), Czapeck Dox agar (CDA), nutrient agar (NA) and Sabouraud dextrose agar (SDA) were used to note down the differences regarding to various characteristics appeared due to dissimilation of culture medium. Thereafter, the growth environment and medium contents were changed to evaluate the effect of temperature, $\mathrm{pH}$, carbohydrate, sugar concentration, salt, organic acid etc. on the mycelial growth of the concerned fungus. In the experiment, these parameters significantly influenced the growth pattern of the fungus. For proper identification of the fungus, advanced molecular technique was used. The PCR product of the internal transcribed spacer (ITS) region of the fungi showed nearly $650 \mathrm{bp}$ size of clear band followed by sequencing of the PCR product of the fungus. The sequenced data showed $99 \%$ similarities with the original sequence of Choanephora cucurbitarum. In search of suitable biocontrol measure, the antifungal activities of the seven plant extracts namely Hibiscus rosa-sinensis, Ficus racemosa, Moringa oleifera, Psidium guajava, Azadirachta indica, Cassia alata and Coccinia grandis were assayed where Azadirachta indica $(42.12 \%)$ and Moringa oleifera (35.71\%) had promising inhibitory effects against the isolated fungus. The outcome of the experiment would be benevolent for the detection and development of eco-friendly control approach of the detrimental disease of the bitter gourd.
\end{abstract}

Keywords: Momordica charantia; Choanephora fruit rot disease; Characterizations; Bio-control

\section{Introduction}

The Cucurbitaceae is a medium sized family of dicotyledons consisting of an excellent example of a plant family with many economically useful species [1]. Though many species of the family are cultivated for edible purposes [2], they are also known to contain many bioactive compounds such as cucurbitacins, triterpenes, sterols and alkaloids [3] that have anti-inflammatory, antitumor, hepato-protective, cardiovascular and immune-regulatory activities [4-5]. Momordica charantia (L.), bitter gourd one of the most important member of Cucurbitaceae family, is a flowering vine that widely cultivated in Asia, East Africa, and South America [6] for its intensely bitter fruits that are commonly used in cooking

${ }^{*}$ Corresponding author: Hasan Md. Faruk

Copyright (C) 2020 Author(s) retain the copyright of this article. This article is published under the terms of the Creative Commons Attribution Liscense 4.0. 
and as healer [7] for treating various diseases [8]. It is a climbing perennial that usually grows up to 5 meters, and bears elongated fruits with a knobbly surface. Bitter melon is one of the most popular vegetable in Asia where it is grown on approximately 340,000 hector annually by smallholder farmers [9]. In Bangladesh, the commercial cultivation of bitter gourd is very successful which covered around 23,890 acres of cultivable lands and the total production is nearly 52,020 metric tons per annum [10]. The success of any crop production generally depends on the profitability at farm level. Bitter gourd producing farmers often fail to obtain the expected yield due to the infestation of the crops by insect-pests and diseases and non-adoption of plant protection measures by farmers [11]. According to Muthuraman \& Kumar [12] report, the losses ranging from $20-30 \%$ are resulted from each of the insect-pests, diseases and weeds. Among the various diseases inflicting bitter gourd, Choanephora fruit rot is one of the most devastating diseases that also affect other cucurbits [13]. The disease is caused by the fungus Choanephora cucurbitarum that is favored by extended period of warm and wet weather and the symptom of the disease includes soft, rotted blossom end covered with fluffy purplish black fungal growth. The catastrophic loss caused by the diseases implies that suitable control measures must be followed to keep these losses to the minimum [12]. But the intensive and indiscriminate use of pesticides in agriculture has caused many problems to the environment and responsible for food contamination, poisoning of farmers, and elimination of non-target organisms [14]. On the other hand, plants have ability to synthesize aromatic secondary metabolites, like phenols, phenolic acids, quinones, flavones, flavonoids, flavonols, tannins and coumarins [15]. These groups of compounds show antimicrobial effect and may take part in plant defense mechanisms against pathogenic microorganisms [16]. The present study was purposed to evaluate the antifungal potential of some plant extracts against the phyto-pathogenic fungi Choanephora cucurbitarum along with its identification and characterization.

\section{Material and methods}

\subsection{Collection of diseased sample}

The disease infected immature fruits (figure 1) was collected into closed paper envelop [17] from the field of bitter gourd in Naogaon, Rajshahi, Bangladesh and the disease was identified by Dr. Asraful Islam, Scientific Officer, Fruit Research Institute, Binodpur, Rajshahi. The experiment related to the disease and causal agent was conducted at Professor Joarder DNA and Chromosome Research Lab., Department of Genetic Engineering and Biotechnology, University of Rajshahi, Bangladesh.

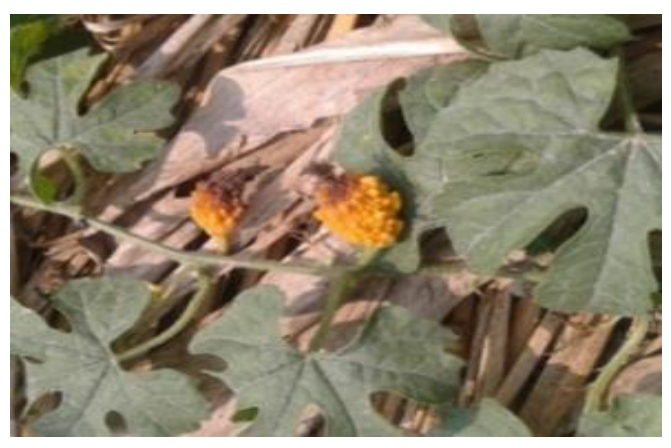

Figure 1 Showing the disease infected fruit sample of bitter gourd

\subsection{Isolation of the pathogen responsible for the disease}

At the laboratory, the infected fruit tissues were excised with a sterilized razor blade at the point of progression of disease symptom; then surface sterilized by $70 \%$ ethanol solution for 2 minutes. The tissues were then washed with sterilized distilled water three times and were placed on sterile paper towels for drying [18], followed by incubation on PDA (Hi-Media, India) at $25{ }^{\circ} \mathrm{C}$ in the dark for 3 days. The medium was supplemented with $0.5 \mathrm{gL}^{-1}$ of streptomycin sulphate (Sigma-Aldrich, USA) and $1 \mathrm{mlL}^{-1}$ of lactic acid. The mycelium emerged from diseased sample were re-isolated using a single spore technique [19] and transferred onto the Petri plate of new fresh PDA medium for the incubation of 7 days.

\subsection{Morphological and microscopic identification}

The isolated fungi were identified according to colony morphology and microscopic examination. Fungal colonies were grown onto PDA medium for species identification. The purified fungi were identified according to the fungal morphological characteristics as described in several previous studies [20-22]. The characteristics such as diameters, 
overall colors, colors of conidia, texture, form, margin, reverse colors, elevation, opacity, dry weight, sporulation, and zonation were studied.

\subsection{Growth profiling of the fungal isolate}

In general, various artificially made growth medium are used for the study of fungi that influence the mycelial growth and colony morphology of the concerned fungi [23].

In our study, PDA (Hi-Media, India), CDA (Hi-Media, India), NA (Hi-Media, India) and SDA (Hi-Media, India) media were used for observation of various characteristics in response to different culture medium. After incubation of 7 days in dark, different morphological characteristics of the fungal colonies such as form, margin, elevation, surface, opacity, front colour, back colour and dry weight were observed [24]. To determine the effect of temperature on the growth of the fungal strain, the fungal Petri plates were kept in $15^{\circ} \mathrm{C}, 20{ }^{\circ} \mathrm{C}, 25{ }^{\circ} \mathrm{C}, 30^{\circ} \mathrm{C}$ and $35^{\circ} \mathrm{C}$ temperature, respectively. Thereafter, the carbohydrates dextrose, fructose, lactose, maltose and starch were used as sole carbon source in modified PDA media to check the effect of carbohydrates on the growth of fungi. For the growth profiling in different concentrations of sugar, $3 \%, 6 \%, 9 \%, 12 \%, 15 \%$ and $18 \%$ of dextrose were added in PDA media instead of $2 \%$ dextrose. To study about the effect of salts on the mycelia of the strain, $5 \%$ of different salts named $\mathrm{CaCl}_{2}, \mathrm{MgCl}_{2}, \mathrm{MgSO}_{4}, \mathrm{NaCl}$ and $\mathrm{KCl}$ were included in the PDA medium. The effect of organic acids on the growth of fungi was also estimated by adding $1 \%$ of citric acid, malic acid and nicotinic acid separately in PDA medium and incubating it at dark for 7 days.

\subsection{Molecular identification}

Identifying fungi based on morphology alone may be challenging, and this practice is no longer acceptable according to the latest International Code of Nomenclature for algae, fungi, and plants [25-26]. As a consequence, DNA sequencebased methods have been widely used for identifying species within the mega diverse fungi [27-30]. According to Schoch et al., [31] ITS region has highest probability among all the markers used in case of correct identification for broader group of fungi. ITS markers are easier to amplify from small quantity of DNA as well as it has a high degree of variation even between closely related species [32]. Moreover, additional fungal studies have provided support for the ITS region as a suitable fungal barcode [33-35].

For DNA extraction, 1g of mycelia (fresh weight) was taken from 7 days old culture grown on PDA media. The genomic DNA was then isolated by using MaxMaxwell ${ }^{\circledR} 16$ LEV Plant DNA Kit (AS1420, Promega, USA). The isolated DNA was then subjected to PCR technique to amplify specific region of the extracted DNA where universal primers, ITS4 (5'TCCTCCGCTTAT TGATATGC -3') and ITS5 (5'-GGAAGTAAAAGTCGTAACAAGG-3') were used. In case of PCR amplification, $25 \mu \mathrm{l}$ of a reaction mixture containing $2 \mu \mathrm{l}$ genomic DNA, $2.5 \mu \mathrm{l} 1 \mathrm{X}$ PCR buffer, $1.0 \mu \mathrm{l} \mathrm{MgCl}, 1.5 \mu \mathrm{lNTPs}$, $0.5 \mu \mathrm{l}$ of each primer, $0.5 \mu \mathrm{l}$ of Taq polymerase and $16.5 \mu \mathrm{l}$ of deionized water were used [36]. Afterward, the PCR was programmed with an initialization step at $95^{\circ} \mathrm{C}$ for $2 \mathrm{~min}$, followed by 32 cycles of denaturation at $95^{\circ} \mathrm{C}$ for 30 seconds, primer annealing at $48{ }^{\circ} \mathrm{C}$ for 30 seconds, and extension at $72{ }^{\circ} \mathrm{C}$ for 45 seconds and a final extension at $72{ }^{\circ} \mathrm{C}$ for 10 minutes. PCR products were separated by electrophoresis on $1.5 \%$ agar gel with $0.5 \%$ Ethidium bromide in $1 \mathrm{x}$ TAE buffer and visualized under UV light. After that the amplified DNA was purified, followed by sequencing in sequencing service laboratory, National Institute of Biotechnology (NIB), Bangladesh. The sequenced nucleotide data were analyzed through the BLAST program provided by the National Center for Biotechnology information (NCBI) (http://blast.ncbi.nlm.nih.gov) and finally, phylogenetic tree was constructed by using the data.

\subsection{In vitro screening of extracts presenting antifungal activity}

Many studies revealed the antimicrobial properties of numerous plant species with increasing attention on herbal, medicinal, and aromatic plants for their antifungal activities [37]. For evaluating antimicrobial effect of plant extracts on the growth of isolated fungi, seven plant species were applied namely China rose, common fig, drumstick, guava, neem, ringworm shrub and scarlet gourd. For conducting the study, around $2 \mathrm{~g}$ cleaned fresh leaves were sterilized with $0.1 \%$ mercuric chloride followed by washing with distilled water. Thereafter, methanol $(10 \mathrm{ml})$ was used as solvent. After that the leaves were grounded by mortar-pestle and subjected to centrifugation for 10 minutes (12000 rpm), which was then filtered through muslin cloth, followed by Whatman filter paper. After filtration, the supernatant was stored into refrigerator at $4{ }^{\circ} \mathrm{C}$.

For evaluating antifungal activity of the leaf extracts, slightly modified poisoned food technique [38] was applied where $50 \mu \mathrm{g}$ of plant extract were added at $20 \mathrm{ml}$ of PDA medium. Then, medium-extract mixture was properly shacked and poured into petri plates. A fungal plug ( $6 \mathrm{~mm}$ diameter) was cut from 7 days old fungal culture and inoculated at the center of each Petri plate to investigate their inhibitory effectiveness on the growth of the fungal strain. The Petri dish inoculated with fungal disc alone served as control. Lastly, the Petri plates were incubated at $25 \pm 2{ }^{\circ} \mathrm{C}$ for 7 days in static 
condition. Subsequently, the inhibition of the growth was calculated by Arora and Dwivedi method [39]. According to the method, and the inhibition percentage of mycelial growth $=\left[\left(\mathrm{G}_{\mathrm{c}}-\mathrm{G}_{\mathrm{t}}\right) / \mathrm{G}_{\mathrm{c}}\right] \times 100$

Where, $\mathrm{G}_{\mathrm{c}}=$ Mycelial growth in case of colony diameter in control set,

$\mathrm{G}_{\mathrm{t}}=$ Mycelial growth in terms of colony diameter in treatment set

\section{Results}

\subsection{Isolation of the pathogen}

In our study, after sterilization collected sample was incubated on PDA medium that followed by single spore technique, and at the end of seven days, yellow colored fungal colonies were appeared. Through the procedure, the fungal pathogen was isolated and culture as single colony (images are not given).

\subsection{Morphological and microscopic identification}

All four culture media showed variability in the growth of the isolated fungi to various degrees (table 1). The fungus showed maximum dry weight of $482 \mathrm{mg}$ on PDA media after 7 days of incubation period. Moreover, differences in surface and reverse colouration of fungal colonies were distinct on the growth media (figure 2). The study of cotton blue staining revealed that sporangiophores bearing sporangiola were hyaline, unbranched, apically dilated to form a clavate vesicle. The monosporous sporangiola were brown in colour, ellipsoid to ovoid, 10-14 $\mu \mathrm{m}$ in width and 11-20 $\mu \mathrm{m}$ in length.

Table 1 Colony morphology of the fungal strain on different media

\begin{tabular}{|c|c|c|c|c|}
\hline Characteristics & $\begin{array}{l}\text { Potato dextrose } \\
\text { agar }\end{array}$ & $\begin{array}{l}\text { Czapek Dox } \\
\text { agar }\end{array}$ & Nutrient agar & $\begin{array}{l}\text { Sabouraud } \\
\text { dextrose agar }\end{array}$ \\
\hline Form & Filamentous & Filamentous & Filamentous & Filamentous \\
\hline Margin & Filiform & Filiform & Filiform & Undulate \\
\hline Elevation & Raised & Flat & Curled & Flat \\
\hline Surface & Filiform & Filiform & Filiform & Filiform \\
\hline Opacity & Non opaque & Non opaque & Non opaque & Non opaque \\
\hline Front colour & Yellow & Yellow & Off white & Light yellow \\
\hline Back colour & Flaxen & Flaxen & Off white & Light yellow \\
\hline Dry weight (mg) & 482 & 153 & 376 & 202 \\
\hline
\end{tabular}




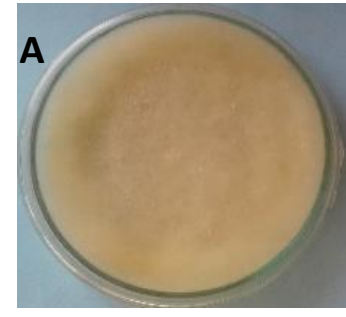

PDA

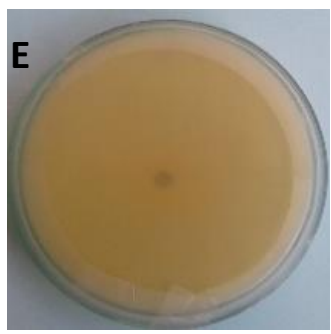

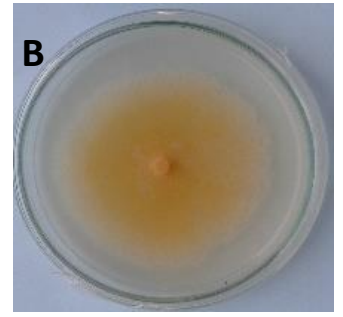

CDA

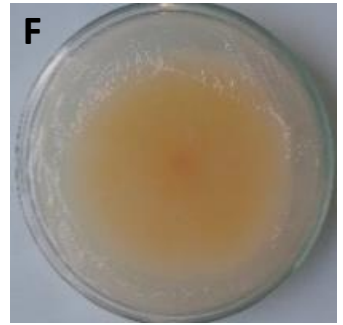

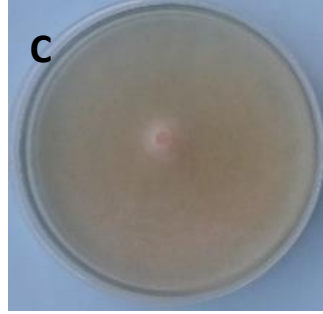

NA

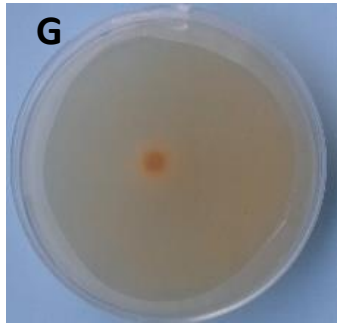

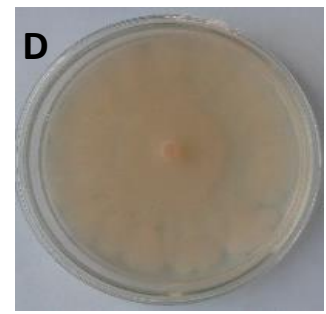

SDA

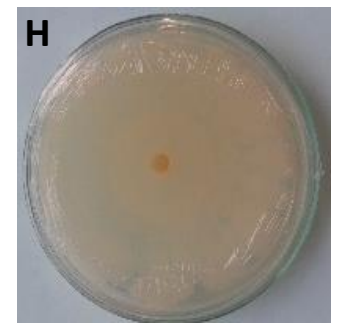

Figure 2 Effects of the fungal isolate on different media; aerial mycelial growth (A, B C, D) and the vegetative mycelial growth (D, E, F, G)

\subsection{Growth profiling of the fungal isolate}

\subsubsection{Effect of temperatures on the growth of the fungal strain}

The fungal growth of the strain was estimated in $15^{\circ} \mathrm{C}, 20^{\circ} \mathrm{C}, 25{ }^{\circ} \mathrm{C}, 30^{\circ} \mathrm{C}$ and $35^{\circ} \mathrm{C}$ where it achieved highest growth at $25^{\circ} \mathrm{C}$. On the other hand, the minimum growth was observed at $35^{\circ} \mathrm{C}$ (figure $3 \mathrm{~A}$ ).

\subsubsection{Effect of $\mathrm{pH}$ on the growth of the fungal strain}

From the study, it was established that $\mathrm{pH} 5$ was the most favorable $\mathrm{pH}$ for the mycelial growth whereas $\mathrm{pH} 7$ provided least helpful environment to the fungal isolate for growth (figure 3B).

\subsubsection{Effect of carbohydrates on the growth of the fungal strain}

In the study, the highest dry weight of the fungi was nearly $419 \mathrm{mg}$ in case of dextrose containing culture media while the lowest was $347.33 \mathrm{mg}$ having lactose in PDA (figure 3C).

\subsubsection{Effect of sugar concentrations on the growth of the fungal strain}

In the experiment, the fungal isolate was subjected to several sugar concentrations to evaluate the effect of sugar concentrations on the growth of the fungus. The mycelial dry weight for $3 \%, 6 \%, 9 \%, 12 \%, 15 \%$ and $18 \%$.sugar concentrations were $344 \mathrm{mg}, 369 \mathrm{mg}, 397 \mathrm{mg}, 203 \mathrm{mg}, 150 \mathrm{mg}$, and $118 \mathrm{mg}$, respectively (figure 3D).

\subsubsection{Effect of salts on the growth of the fungal strain}

In case of the concerned fungal isolate, the highest growth was noted down for the salt, $\mathrm{MgCl}_{2}$ whereas the $\mathrm{NaCl}$ showed lowest mycelial growth (figure 3E).

\subsubsection{Effect of organic acids on the growth of the fungal strain}

The fungi grew well in citric acid at $1 \%$ concentration in comparison to other acids tested. On the other hand, the growth decreased most in malic acid and the dry weight was $35 \mathrm{mg}$ (figure 3F). 

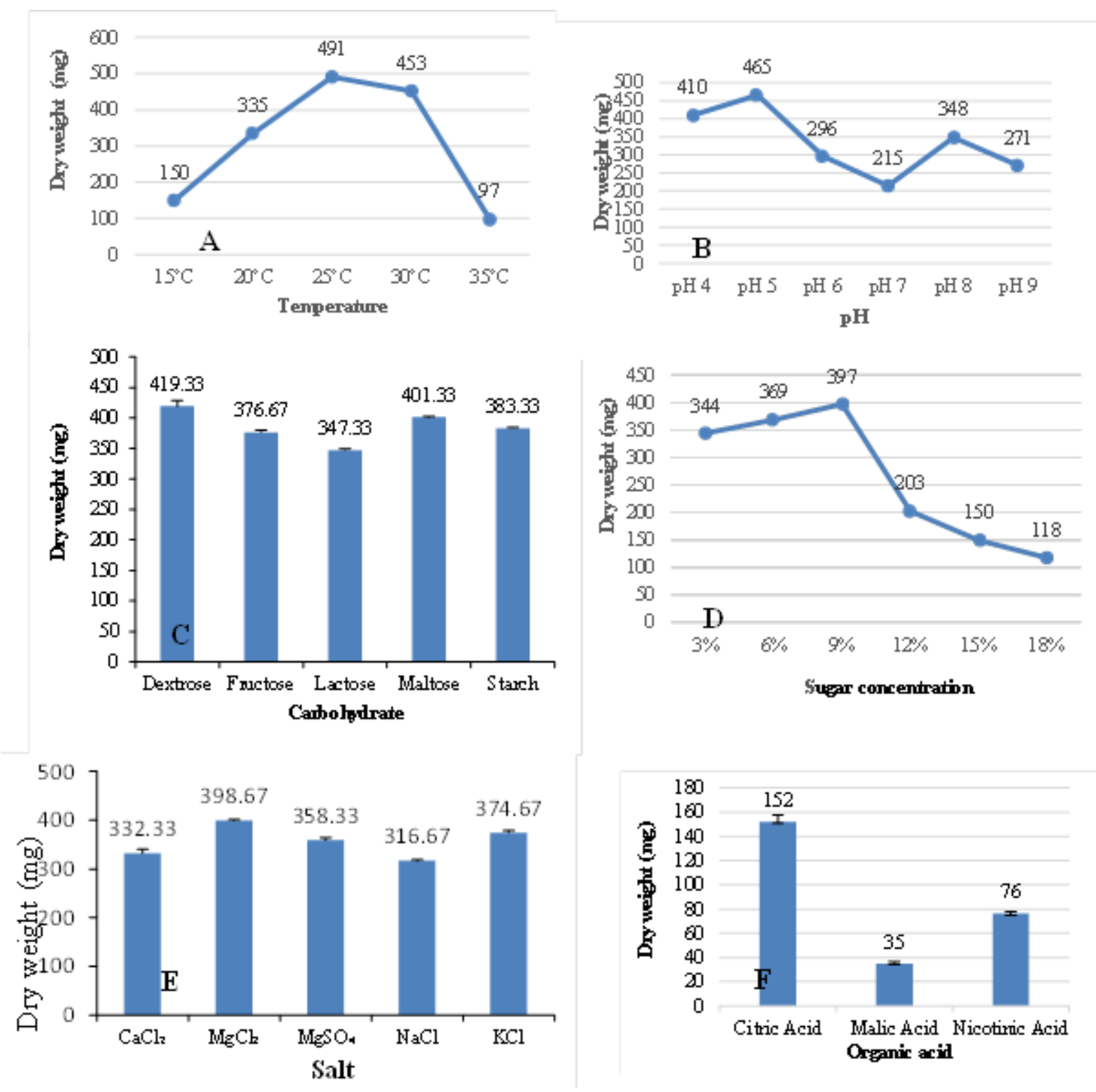

Figure 3 The effects of different parameters on growth pattern of isolated fungi; (A) temperatures, (B) pH, (C) carbohydrates, (D) sugar (E) salts and (F) organic acids.

\subsection{Molecular characterization}

\subsubsection{PCR amplification}

Upon extraction of the genomic DNA using DNA isolation kit', the extracted DNA was run on 1\% agarose gel and visualized in gel documentation system. The 'ITS' region of ribosomal DNA was amplified through PCR technique with ITS4 and ITS5 primers and it produced approximately $650 \mathrm{bp}$ bright band where $1 \mathrm{~kb}$ DNA ladder was used as marker (figure 4). The sequenced 'ITS' region was then was subjected to BlastN search in GenBank (https://www.ncbi.nlm.nih.gov) for proper identification of the isolate. 


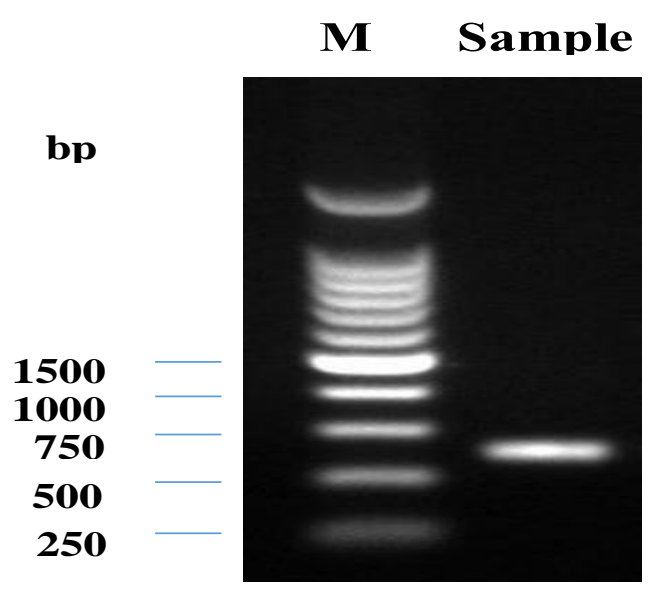

Figure 4 PCR amplification of ITS region yielded $\sim 650$ bp product, 1kb DNA marker (M) is used for size determination

\subsubsection{Sequencing and phylogenetic tree construction}

The 18S of rDNA sequence of the fungal strain revealed 99\% similarity with the original sequence of Choanephora cucurbitarum (data not shown). To draw phylogenic relationship, the sequences of different Choanephora spp. were downloaded in FASTA format from the GenBank and the data was then aligned to construct phylogenetic tree (figure 5).

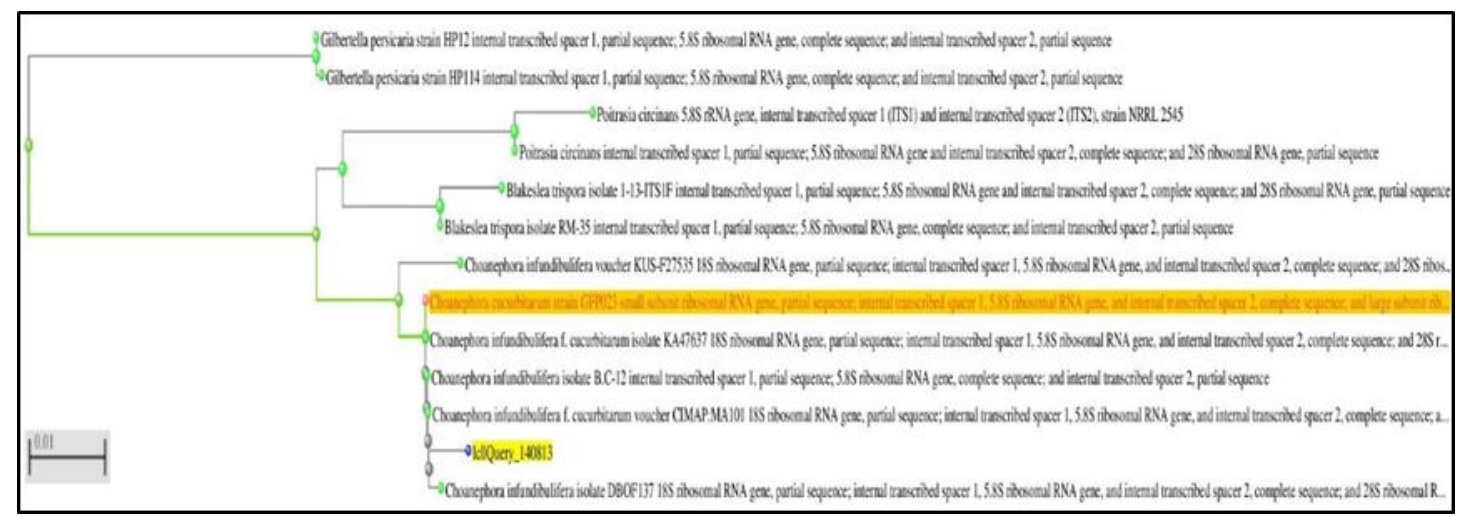

Figure 5 Phylogenetic relationship of the isolated fungal strain

\subsection{In vitro screening of extracts presenting antifungal activity}

In the experiment, seven different types of plants extracts were used (figure 6). Among them, Azadirachta indica (42.12\%) and Moringa oleifera (35.71\%) had highest inhibitory effects on the isolated fungus. Moreover, Coccinia grandis (31.78\%), Hibiscus rosa-sinensis (26.21\%) and Cassia alata $(16.01 \%)$ had prominent negative effects on the growth of the fungus, but the Psidium guajava (4.44\%) and Ficus racemosa $(10.35 \%)$ had very low antifungal effects on the fungal isolate in comparison to other plant extracts. 


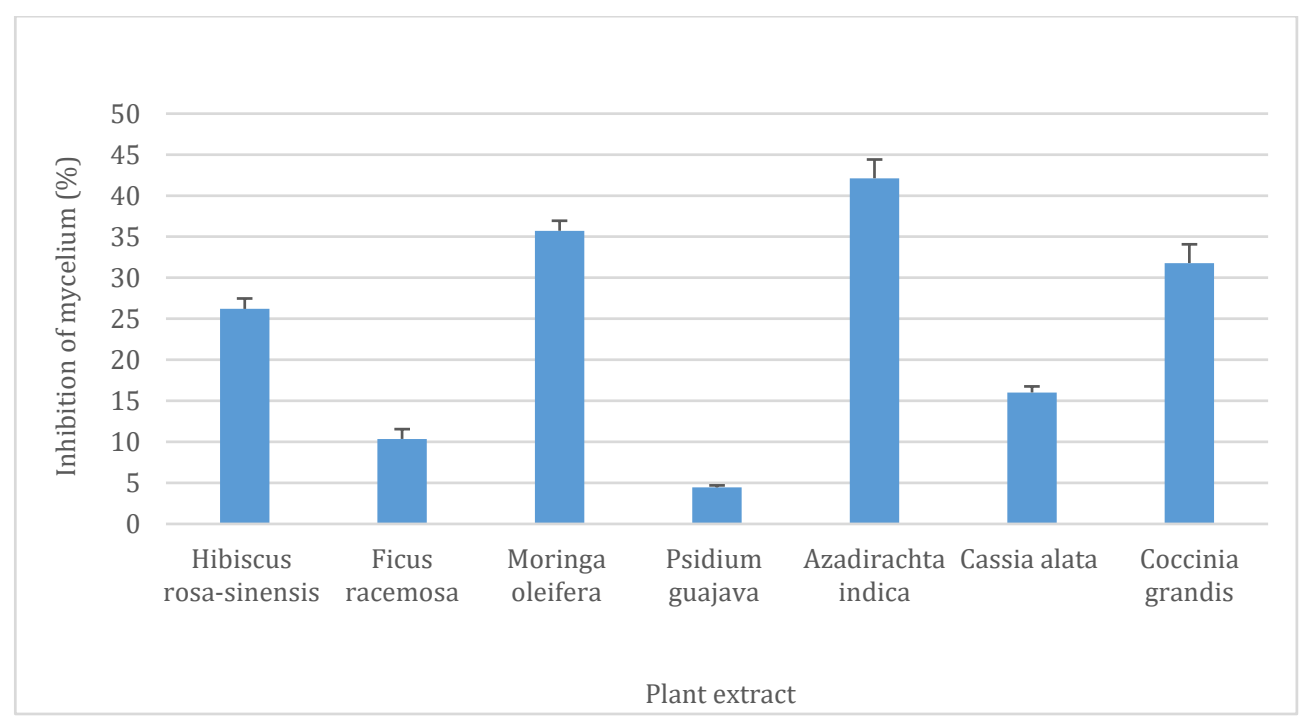

Figure 6 The effect of plant extracts on the inhibition of mycelial growth of the isolated fungi

\section{Discussion}

Agriculture is the backbone and synonymous to the food security of a country [40]. In particular, it is the contributor of income and employment generation in Bangladesh [41]. Therefore, most of the farmers are marginally occupying subsistence farming and crop production raises rural income and creates jobs for poor people [42]. According to many researchers, crop losses are admittedly major threat to the wellbeing of rural families, to the economy of traders and governments, and to food security worldwide [43-45]. At the same time, crop losses due to pests and diseases for major food and cash crops were estimated between $20 \%$ and $40 \%$ at country and regional levels in different continents [4647].

Bitter gourd is suffering from various diseases of which the fungal disease, Choanephora fruit rot caused by Choanephora cucurbitarum has become one of considerable constraints in bitter gourd growing area resulting in poor yields and reduced quality. Kacharek et al., [13] also reported that Choanephora cucurbitarum is a plant pathogenic fungus causing fruit rots, flower rot and leaf blights on a variety of plants.

Pathogen was isolated from the symptomatic infected fruit part on potato dextrose agar (PDA) under the temperature of $25 \pm 2{ }^{\circ} \mathrm{C}$ which was similar with the study of Saroj et al., [48]. In our experiment, PDA media was proved as most effective culture media to support mycelial growth of the fungal isolate. Several researchers [49] also stated PDA to be the best media for mycelial growth which was consistent with our findings. In our study, $25{ }^{\circ} \mathrm{C}$ was the suitable temperature for the fungi, while the optimum $\mathrm{pH}$ was 5. Kuo et al., [50] and Abdel-Motaal et al., [51] stated $25{ }^{\circ} \mathrm{C}-30{ }^{\circ} \mathrm{C}$ temperature as optimum for mycelial growth of Choanephora cucurbitarum which supported our observation. From the previous studies, it was established - acid/alkaline requirement for growth of fungi is quite broad, ranging from $\mathrm{pH} 3.0$ to more than $\mathrm{pH}$ 8.0, with optimum around $\mathrm{pH} 5.0$ if nutrient requirements are satisfied [52]. It was observed from our experiment that the maximum growth was achieved in dextrose and in case of $9 \%$ sugar concentration, respectively. In general, increasing in concentration of dextrose sugar up to $2.0 \%$ gave least response for mycelial growth, whereas further increase in concentration of dextrose sugar did not prove feasible. Our findings were in conformity with other experts $[48,53]$ who studied the carbon requirement on Pleurotus ostreatus and $P$. florida and showed that dextrose was the best carbon source. The addition of organic acid and salt significantly decreased the mycelial growth of our fungal isolate. The effect of organic acids on the fungal growth has been investigated by several authors [54-56]. Similarly, several studies have dealt with the use of different salt compounds to control various post-harvest diseases of Citrus and other crops [57-59].

The molecular identification of fungus was performed by sequencing of the ITS regions [60]. A nucleotide BLAST search of the publicly available fungal database showed that the $622 \mathrm{bp}$ sequence of the ITS-rDNA region exactly matched with the Choanephora cucurbitarum with 99\% similarity. Phylogenetic analysis was done with comparative analysis of different ITS-rDNA regions of NCBI published databases. 
Plant extracts are now superior choice to control different plant pathogens that have been reported by several researches [61-63]. From our experiment, it was found that methanolic plant extract of neem, drumstick, scarlet gourd etc showed highest inhibitory effects against the fungal strain. The findings are consistent with the findings of Singh et al., [64] who reported that fungicidal and bactericidal properties of extracts from neem leaves either in vitro or in vivo trials to the presence of several antimicrobial active ingredients in leaves of neem tree such as desactylimbin, quercetin and sitosterol. Meanwhile, according to Ayanbimpe et al., [65], saprophytic fungi were also found to be inhibited by the extract of Moringa oleifera leaves.

\section{Conclusion}

In the present investigation, morphological characteristics of the fungal isolate unfolded a great extent of differences when the fungus was grown in varied conditions of culture medium and environmental factors. The inequality in the nutrition revealed about their optimum requirements to achieve the highest growth as well as provided information about the unfavorable factors in case of their mycelial growth. Along with these studies, the molecular technique sequencing was supplemented for proper identification of the fungal isolate which disclosed the identity of the fungal isolate as Choanephora cucurbitarum which is the causal agent of the disease, Choanephora fruit rot in bitter gourd that responsible for significant economic loss of the bitter gourd producing farmers. At the same time, some plant extracts displayed commendable inhibitory effects against the pathogenic fungal strain which may assist to prevent the exaggerated disease of bitter gourd in near future.

\section{Compliance with ethical standards}

\section{Acknowledgments}

The authors are grateful to the Dean, Faculty of Biological Sciences, University of Rajshahi, Bangladesh for providing financial support during the research works.

\section{Disclosure of conflict of interest}

The authors declare that there is no conflict of interests regarding the publication of this paper.

\section{References}

[1] Rubatzky VE and Yamaguchi M. (1997). World vegetables principles, production, and nutritive values. Fruits, 5(51), 381.

[2] Ajuru M and Ajuru G. (2014). Indigenous and Exotic Cucurbits in Nigeria. Current Advances in Plant Sciences Research, 1 (1), 12-17.

[3] Abdelwahab SI, Hassan LEA, Sirat HM, Yagi SMA, Koko WS, Mohan S and Rais MM. (2011). Anti-inflammatory activities of cucurbitacin E isolated from Citrullus lanatus var. citroides: role of reactive nitrogen species and cyclooxygenase enzyme inhibition. Fitoterapia, 82(8), 1190-1197.

[4] Shweta SS, Priyanka KT, Ganesh GT and Khadabadi SS. (2003). Ancient and Recent Medical Uses of Cucurbitaceae Family. International Journal of Therapeutic Applications, 9, 11-194.

[5] Dhiman K, Gupta A, Sharma DK, Gill NS and Goyal A. (2012). A review on the medicinally important plants of the family Cucurbitaceae. Asian Journal of Clinical Nutrition, 4(1), 16-26.

[6] Gupta M, Sharma S, Gautam AK and Bhadauria R. (2011). Momordica charantia Linn. (Karela): Nature’s silent healer. International Journal of Pharmaceutical Sciences Review and Research, 11(1), 32-37.

[7] Abascal K and Yarnell E. (2005). Using bitter melon to treat diabetes. Alternative \& Complementary Therapies, 11(4), 179-184.

[8] Palada MC and Chang LC. (2003). Suggested cultural practices for bitter gourd. AVRDC International Cooperators' Guide, 03-547.

[9] McCreight JD, Staub JE, Wehner TC and Dhillon NP. (2013). Gone global: familiar and exotic cucurbits have Asian origins. Hort. Science, 48(9), 1078-1089. 
[10] BBS (2013). Yearbook of Agricultural Statistics of Bangladesh, Ministry of Planning, Government of the People's Republic of Bangladesh, Dhaka.

[11] Bhalekar MD, Sidam VN, Bondarwad SP and Lad AS. (2013). Constraints in adoption biological pest management practices in cotton in Vidarbha region. Agriculture Update, 8(1/2), 70-72.

[12] Muthuraman P and Kumar SA. (2013). Crop Growth Stage-wise IPM Practices in Rice. Kisan World, 40(4), 57-59.

[13] Kacharek TA, Benny GL and Pernezny K. (2003). Choanephora blight (wet rot), Minnesota. Phytopathol. Soc. Pre., St Paul, MN, 11-12.

[14] Stangarlin JR, Schwan-Estrada KRF, Cruz MES and Nozaki MH. (1999). Medicinal plants and alternative control of phytopathogens. Biotecnologia Ciência \& Desenvolvimento, 11, 16-21.

[15] Cowan MM. (1999). Plant products as antimicrobial agents. Clinical microbiology reviews, 12(4), 564-582.

[16] Das K, Tiwari RKS and Shrivastava DK. (2010). Techniques for evaluation of medicinal plant products as antimicrobial agent: Current methods and future trends. Journal of medicinal plants research, 4(2), 104-111.

[17] Zainab MB and Shinkafi SA. (2016). Isolation and identification of fungi responsible for leaf spots disease of mango (Mangifera indica L.) in Sokoto state, Nigeria. Bayero Journal of Pure and Applied Sciences, 9(2), 166-173.

[18] Okigbo RN and Osuinde MI. (2003). Fungal leaf spot diseases of mango (Mangifera indica L.) in Southeastern Nigeria and biological control with Bacillus subtilis. Plant protection science-prague, 39(2), 70-78.

[19] Gams W, Hoekstora ES and Aptroot A. (1998). CBS Course of mycology, 4th Ed., Centrall bureau voor schimmelcultures, Baarm, The Netherlands.

[20] Booth C. (1977). Fusarium. Laboratory guide to the identification of the major species. Commonwealth Mycological Institute.

[21] Barnett HL and Hunter BB. (1986). Illustrated Genera of Imperfect Fungi. 4th ed. Macmillan Publishing Co., New York. 218p

[22] Leslie JF and Summerell BA. (2006). Fusarium laboratory manual. Blackwell Publishing. 388p. www.blackwellprofessional.com. SB741.F9L47.

[23] Kumara KL and Rawal RD. (2010). Influence of carbon, nitrogen, temperature and pH on the growth and sporulation of some Indian isolates of Colletotrichum gloeosporioides causing anthracnose disease of papaya (Carrica papaya L). Tropical Agricultural Research and Extension, 11.

[24] De Hoog GS and Guarro J. (1995). Atlas of clinical fungi: Centraalbureau voor schimmel cultures. 2000 No.Ed, 2, 1126.

[25] Hibbett DS and Taylor JW. (2013). Fungal systematics: Is a new age of enlightenment at hand? Nature Reviews Microbiology, 11(2), 129-133.

[26] Hawksworth DL. (2011). A new dawn for the naming of fungi: impacts of decisions made in Melbourne in July 2011 on the future publication and regulation of fungal names. MycoKeys 1: 7-20. IMA Fungus, 2, $155-162$.

[27] Hibbett DS, Ohman A, Glotzer D, Nuhn M, Kirk P and Nilsson RH. (2011). Progress in molecular and morphological taxon discovery in Fungi and options for formal classification of environmental sequences. Fungal Biology Reviews, 25(1), 38-47.

[28] Hibbett DS. (1992). Ribosomal RNA and fungal systematics. Trans Mycol Soc Jpn, 33, 533-556.

[29] Taylor JW and Hibbett DS. (2013).Toward sequence-based classification of fungal species. IMA Fungus, 4(2), 3334.

[30] Bridge PD, Spooner BM and Roberts PJ. (2005). The impact of molecular data in fungal systematics. Advances in Botanical Research, 42, 33-67.

[31] Schoch CL, Seifert KA, Huhndorf S, Robert V, Spouge JL and Levesque CA. (2012). Fungal Barcoding Consortium. Nuclear ribosomal internal transcribed spacer (ITS) region as a universal DNA barcode marker for Fungi. Proceedings of the National Academy of Sciences, 109(16), 6241-6246.

[32] Baldwin BG. (1992). Phylogenetic utility of the internal transcribed spacers of nuclear ribosomal DNA in plants: an example from the Compositae. Molecular phylogenetics and evolution, 1(1), 3-16. 
[33] Kelly LJ, Hollingsworth PM, Coppins BJ, Ellis CJ, Harrold P, Tosh J and Yahr R. (2011). DNA barcoding of lichenized fungi demonstrates high identification success in a floristic context. New Phytol. 191, 288-300.

[34] Dentinger BTM, Didukh MY and Moncalvo JM. (2011). Comparing COI and ITS as DNA Barcode Markers for Mushrooms and Allies (Agaricomycotina). PLoS ONE, 6(9), e25081.

[35] Seena S, Pascoal C, Marvanovä L and Cássio F. (2010). DNA barcoding of fungi: A case study using ITS sequences for identifying aquatic hyphomycete species. Fungal diversity, 44(1), 77-87.

[36] Pitt JI and Samson RA. (2014). Integration of modern taxonomic methods for Penicillium and Aspergillus classification. CRC Press.

[37] El-Nagerabi SA, Elshafie AE, AlKhanjari SS, Al-Bahry SN and Elamin MR. (2013). Biological activities of Boswellia sacra extracts on the growth and aflatoxins secretion of two aflatoxigenic species of Aspergillus species. Food control, 34(2), 763-769.

[38] Nene YL and Thapliyal PL. (1979). Disease fungicides in plant control. Fungicides in plant disease control. . Oxford and IBH Publishing Company, New Delhi, 507.

[39] Arora DK and Dwivedi RS. (1979). Rhizosphere fungi of Lens esculenta Moench antagonistic to Sclerotium rolfsii Sacc. Soil Biology and Biochemistry, 11(6), 563-566.

[40] Planning Commission. (2010). Outline Perspective Plan of Bangladesh 2010-2021- Making Vision 2021, A Reality, Final Draft. General Economics Division, Planning Commission, Government of the People's Republic of Bangladesh, Dhaka, Bangladesh.

[41] Planning Commission. (2009). Millennium Development Goals - Need Assessment and Costing. (2009-2015). Bangladesh. General Economics Division, Planning Commission, Government of the People's Republic of Bangladesh, Dhaka, Bangladesh.

[42] Ministry of Environment and Forest (MoEF). (2009). Bangladesh Climate change Strategy Action Plan, (2009). Government of the People Republic of Bangladesh.

[43] Zadoks JC and Schein RD. (1979). Epidemiology and plant disease management. Epidemiology and plant disease management.

[44] Savary S and Willocquet L. (2014). Simulation modeling in botanical epidemiology and crop loss analysis. The Plant Health Instructor, 173.

[45] Avelino J, Cristancho M, Georgiou S, Imbach, Aguilar L, Bornemann G and Morales C. (2015). The coffee rust crises in Colombia and Central America (2008-2013): impacts, plausible causes and proposed solutions. Food Security, $7(2), 303-321$.

[46] Oerke EC. (2006). Crop losses to pests. The Journal of Agricultural Science, 144(1), 31-43.

[47] Oerke EC, Dehne HW, Schönbeck F and Weber A. (2012). Crop production and crop protection: estimated losses in major food and cash crops. Elsevier.

[48] Saroj A, Kumar A, Qamar N, Alam M, Singh HN and Khaliq A. (2012). First report of wet rot of Withania somnifera caused by Choanephora cucurbitarum in India. Plant disease, 96(2), 290-293.

[49] Maheshwari SK, Singh DV and Sahu AK. (1999). Effect of several nutrient media, pH and carbon sources on growth and sporulation of Alternaria alternata. J. Mycopathol. Res, 37, 21-23.

[50] Kuo CH, Chung WC and Chang CA. (1999). Characterization of the pathogen causing Choanephora wet rot of lima bean in Taiwan. Pl. Patho. Bulle, 8(3), 103-110.

[51] Abdel-Motaal, FF, El-Sayed, MA, El-Zayat SA, Nassar MS and Ito SI. (2010). Choanephora rot of floral tops of Hyoscyamus muticus caused by Choanephora cucurbitarum. Journal of general plant pathology, 76(5), 358-361.

[52] Pardo E, Marin S, Ramos AJ and Sanchis V. (2006). Ecophysiology of ochratoxigenic Aspergillus ochraceus and Penicillium verrucosum isolates. Predictive models for fungal spoilage prevention-a review. Food additives and contaminants, 23(4), 398-410.

[53] Neelam, S, Chennupati S and Singh S. (2013). Comparative studies on growth parameters and physio-chemical analysis of Pleurotus ostreatus and Pleurotus florida Asian J. Plant. Sci, 3, 163-169.

[54] Lin CD and Chen TC. (1995). Relative antifungal efficacies of phosphoric acid and other compounds on fungi isolated from poultry feed. Animal feed science and technology, 54(1-4), 217-226. 
[55] Kang HC, Park, YH and Go SJ. (2003). Growth inhibition of a phytopathogenic fungus, Colletotrichum species by acetic acid. Microbiological research, 158(4), 321-326.

[56] Vermeulen A, Dang TDT, Geeraerd AH, Bernaerts K, Debevere J, Van Impe J and Devlieghere F. (2008). Modelling the unexpected effect of acetic and lactic acid in combination with $\mathrm{pH}$ and aw on the growth/no growth interface of Zygosaccharomyces bailii. International journal of food microbiology, 124(1), 79-90.

[57] Arslan U, Ilhan K and Karabulut OA. (2006). Evaluation of food additives and low-toxicity compounds for the control of bean rust and wheat leaf rust. Journal of phytopathology, 154(9), 534-541.

[58] Nigro F, Schena L, Ligorio A, Pentimone I, Ippolito A and Salerno MG. (2006). Control of table grape storage rots by pre-harvest applications of salts. Postharvest Biology and Technology, 42(2), 142-149.

[59] Arsla U, Ilhan K, Vardar C and Karabulut OA. (2009). Evaluation of antifungal activity of food additives against soil borne phytopathogenic fungi. World Journal of Microbiology and Biotechnology, 25(3), 537-543.

[60] Boysen M, Borja M, Moral C, Salazar O and Rubio V. (1996). Identification at strain level of Rhizoctonia solani AG4 isolates by direct sequence of asymmetric PCR products of the ITS regions. Current Genetics, 29(2), $174-181$.

[61] Parveen S, Wani AH, Ganie AA, Pala SA and Mir RA. (2014). Antifungal activity of some plant extracts on some pathogenic fungi. Archives of Phytopathology and Plant Protection, 47(3), 279-284.

[62] Okigbo RN and Emoghene AO. (2004). Antifungal activity of leaf extracts of some plant species on Mycopharerella fijiensis Morelet, the causal organism of black sigatoka disease in banana (Musa acuminata). KMITL Science Journal, 4(1), 20-31.

[63] Cannon RD, Lamping, Holmes, AR, Niimi, K, Tanabe K, Niimi M and Monk BC. (2007). Candida albicans drug resistance-another way to cope with stress. Microbiology, 153(10), 3211-3217.

[64] Singh UP, Singh H and Singh RB. (1980). The fungicidal effect of neem (Azadirachta indica) extracts on some soilborne pathogens of gram (Cicer arietinum). Mycologia, 72(6), 1077-1093.

[65] Ayanbimpe GM, Ojo TK, Afolabi E, Opara F, Orsaah S and Ojerinde OS. (2009). Evaluation of extracts of Jatropha curcas and Moringa oleifera in culture media for selective inhibition of saprophytic fungal contaminants. Journal of clinical laboratory analysis, 23(3), 161-164.

\section{How to cite this article}

Chowdhury MEK, Chaity AS, Khan A, Ferdouse KJ, Islam MA, Sikdar B and Hasan MF. (2020). Molecular characterization of the pathogen responsible for Choanephora fruit rot disease in Momordica charantia (L.) and establishment of its ecofriendly control measures. GSC Biological and Pharmaceutical Sciences, 11(3), 22-33. 